\title{
HOW GOOD IS MYGURU: THE LECTURERS' PERCEIVED USEFULNESS AND
} ATTITUDE

\author{
Mohamed Nor Azhari Azman ${ }^{1,2 *}$, Arasinah Kamis ${ }^{1}$, Che Ghani Che Kob ${ }^{1}$, Arman Shah \\ Abdullah $^{1}$, Mohammad Adam Jerusalem ${ }^{3}$, Kokom Komariah ${ }^{3}$, Emy Budiastuti ${ }^{3}$ \\ ${ }^{1}$ Universiti Pendidikan Sultan Idris, Malaysia \\ ${ }^{2}$ Universitas PGRI Yogyakarta, Indonesia \\ ${ }^{3}$ Universitas Negeri Yogyakarta, Indonesia \\ *e-mail: mnazhari@ftv.upsi.edu.my
}

\begin{abstract}
The integration of e-learning platforms in the higher education system has been around for a long time and is seen in line with the changes in Industrial Revolution 4.0 (IR4.0). Realizing this, Sultan Idris University of Education (UPSI), Malaysia has developed a Learning Management System (LMS) platform based on Technology Acceptance Model for its members to streamline learning and facilitating processes, namely MYGURU. The purpose of this study was to determine the applicability and attitude of the lecturers towards the used of MYGURU during the teaching, learning and facilitating process. Using a survey method, the study involved 248 lecturers (out of 734 overall lecturers) who were selected using simple random sampling. The questionnaire was distributed by email in 2 months period. The results of this study found the mean score for MYGURU perceived usefulness and mean scores of lecturers' attitude to be at moderate level. The study of attitudes toward MYGURU used was modest, whereas the correlation test showed that there was a significant positive and moderate relationship between perceived usefulness and lecturers' attitude. This study implies that developing a Learning Management System such as MYGURU requires continuous improvement in order to provide a better quality of higher education.
\end{abstract}

Keywords: Technology Acceptance Model, learning management system, perceived usefulness, attitude, higher education, learning

\section{INTRODUCTION}

Technological advances have changed the paradigm of world society in education. Sultan Idris University of Education (UPSI), Malaysia has provided a Learning Management System (LMS) as MYGURU platform. LMS is a web-based learning ecosystem used to disseminate information, communicate and knowledge for education and training (Cidral, Oliveira, Di Felice, \& Aparicio, 2018). The Technology Acceptance Model (TAM) is used to assess lecturers' perceptions of MYGURU usage by making the faculty's use and attitude as a research construct. The education system has undergone a continuous change, with new values and methods that will bring about educational advancement over time. Recognizing and incorporating responsible innovation into education policies and into the classroom can lead to a new era of innovation in and for education (Richter, Hale, \& Archambault, 2019). The integration of e-learning in education has shown disastrous results when it fails to achieve its goals due to the low levels of use by educators despite policy reforms as technology advances (Yeop, 2016).

The traditional method of delivery is seen as less applicable in today's modern education system. This is because the delivery process is seen as preventing students from developing their own learning methods and techniques (Razak, 2017). The primary concern of educational institutions is improving the quality of teaching and student academic performance. Various studies have been conducted to identify factors that influence student learning especially the use of learning techniques that help guide students in the right direction and change students' personal habits and situations (Rivas, Fraile, Chamoso, González-Briones, Rodríguez, \& Corchado, 2019).

The Technology Acceptance Model (TAM) was founded by Fred Davis in 1989. The model is an extension of the Theory of Reasonable Action (TRA) developed by Ajzen \& Fisbein's. Davis's model aims to explore factors that have been identified as having an impact on people's attitudes and behavior in 
accepting information technology. Through this Model, there are five main components namely perceived usefulness (PU), perceived ease of use (PEOU), attitude toward use (ATU), behavior intention (BI) and actual use (AU) to use IT. However, the study was conducted using only perceived usefulness (PU) and attitude (A). According to Davis (1989), PU is the level of consumer psychology to understand a particular system as performance enhancement has direct correlation with A and relationship with BI to use the Learning Management System (LMS) applications. Figure 1 presented the TAM.

The notion of usefulness (PU) is the level of acceptance of an individual who believes that the system is capable of positively impacting it. Consumption is the user's assessment of a matter. When a user feels that a system is useful, they will then assume that the system is useful for application (Elkaseh, Wong, \& Fung, 2015; Zemudin \& Salleh, 2017). The notion of usefulness refers to how much an individual believes the use of technology can improve their performance (Chinyamurindi \& Shava, 2015). The notion of usefulness must be taken into account as it can have a great impact on the formation of attitudes and intentions using e-learning (Ibrahim, Leng, Yusoff, Samy, Masrom \& Rizman, 2017).

Attitude toward use (ATU) is an attitude that an individual demonstrates when using a system and promoting it in the learning process. Attitude is important in shaping an individual's intention in accomplishing something. Attitudes consist of influences, cognitions and behaviors that lead to positive reactions and are able to form the intention to use the system (Hussein, 2017). Knowledge of lecturers' attitudes towards the use of technology and their impact on their work performance is very helpful in integrating technology into the teaching process (Elkaseh et al., 2015).

Hamzah (2007) reported the rapid development of information and communication technology (ICT), UPSI has taken steps to enhance the use of ICT in managed the teaching and learning under the Computer Based Learning Unit (UPBK) during the month June 1999 where to development the electronic learning (e-learning) and computerbased in line with conventional learning. The learning management system provided by the overseas agencies has been terminated due to the problems in provide the service e-learning. Therefore, in 2004 the management has replaced it with course management system developed by the local company known as MyGURU. The application of MyGURU is expected to work improved the quality of teaching and academic profile at UPSI. MyGURU administration submitted to the Center for Teaching and Multimedia Technology (PTPM) while the ICT Center provide the support and assistance with more friendly system this user has many additional features including online discussions, announcements, file sharing and monitoring. The system also allows lecturers controls and modifies the appearance and content of the aligned system with the topics being taught.

Usability perceptions influence consumer attitudes toward e-learning. When users find the system useful, it will change their attitude. Perceived usefulness has a significant relationship with attitude toward e-learning and intention to behave (Sakarji, Nor, Razali, Talib, Ahmad, \& Saferdin, 2019; Salloum, Alhamad, Al-Emran, Monem, \& Shaalan, 2019). The first (1) objective is to identify perceived usefulness of MYGURU use among lecturers, second (2) objective is to identify the attitude of lecturers towards the use of MYGURU and the hypothesis of perceived usefulness is positively related to the attitude of the lecturer to the used of MYGURU.

\section{METHODS}

The design of this study is using a quantitative study, which is a survey method. The study design is a data collection strategy used to collect data. The design of the study was aimed at providing the framework and activities for the data collection and analysis process to answer the research questions that have been developed (Creswell, 2012). The study population was 734 lecturers consisting of nine faculty at UPSI and the method sampling applied for this research is purposive sampling. Referring to Krejcie \& Morgan's (1970) table, the sample size was 248. Krejcie \& Morgan's (1970) developed the formulas for determining the sample size for categorical types of data.

Table 1 is the source of the study's intrusions which contains two study variables in which the perceived usefulness is independent variable and the attitude towards use is dependent 


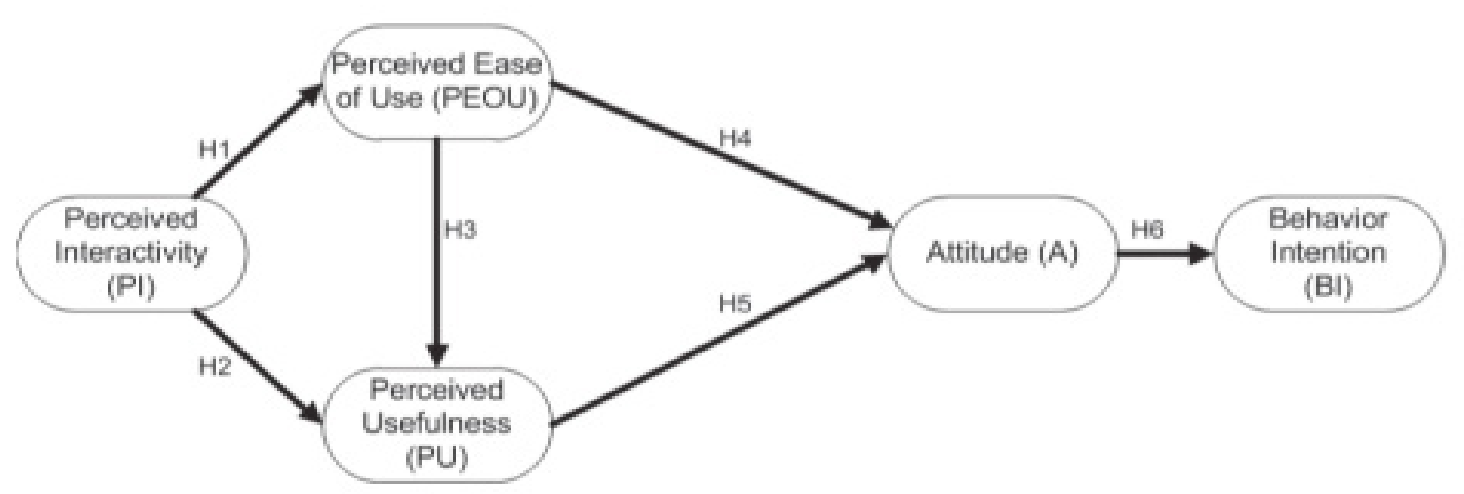

Figure 1. Technology Acceptance Model (David, 1989)

Table 1. The Variables Based on Source and Number of Questions

\begin{tabular}{llc}
\hline Variables & Main References & Number of Items \\
\hline Perceived usefulness & Liaw \& Huang (2011) & 1 \\
(independent variable) & Lin, Persada, \& Nadlifatin (2014) & 1 \\
& Delone \& McLean (2003) & 3 \\
& Ho \& Dzeng (2010) & 2 \\
& Chiu \& Wang (2008) & 1 \\
& Hassanzadeh, Kanaani, \& Elahi (2012) & 1 \\
Attitude & Islam (2014) & 5 \\
(dependent variable) & Liaw \& Huang (2011) & Lin et al. (2014) \\
\hline
\end{tabular}

variable.

Methods of authenticating the content of the instrument used from two panels of experts in education. Intrinsic reliability was conducted in a pilot study with 30 lecturers. The Alpha Cronbach's value is .886 for the perceived the usefulness of MYGURU and .802 for attitudes toward the use of MYGURU which are deemed to be high in its reliability (Creswell, 2012). The final questionnaire was distributed to the study sample by email for a period of 2 months. The analysis of this study uses descriptive analysis and correlation. The interpretation of mean scores for descriptive analysis is shown as Table 2.

Table 2. Mean Classification by Scale

\begin{tabular}{cc}
\hline Mean Scale & Level \\
\hline $3.67-5.00$ & High \\
$2.34-3.66$ & Moderate \\
$1.00-2.33$ & Low \\
\hline Source: Ahmad (2002) &
\end{tabular}

The Spearman's correlation will be used in this study where is a nonparametric measure of the strength and direction of association that exists between two variables measured on at least an ordinal scale.

\section{RESULTS AND DISCUSSION Results}

The findings of this study describe descriptive analysis and inference to answer objectives 1 and 2 .

Objective 1: to identify perceived usefulness of MYGURU use among lecturers.

The mean score for construction items perceived usefulness was modest as the mean value was 3.32 while the standard deviation was .620 (see Table 3).

Objective 2: to identify the attitude of lecturers towards the use of MYGURU.

The mean score for the constructs of attitudes toward MYGURU use was modest as the mean value was 3.03 while the standard deviation was .941 (see Table 4).

Hypothesis (H1): Perceived usefulness is positively related to the attitude of the lecturer to the used of MYGURU. 
Table 3. Perceived Usefulness of MYGURU

\begin{tabular}{|c|c|c|c|c|c|c|c|}
\hline \multirow{2}{*}{ No. Items } & \multicolumn{5}{|c|}{ Frequency of Responses (\%) } & \multirow{2}{*}{ Mean } & \multirow{2}{*}{$\begin{array}{l}\text { Standard } \\
\text { Deviation }\end{array}$} \\
\hline & SD & NA & NS & $\mathbf{A}$ & $\mathbf{S A}$ & & \\
\hline $\begin{array}{l}\text { 1. Able to motivate my learning } \\
\text { and facilitating processes. }\end{array}$ & $\begin{array}{c}6 \\
(2.4)\end{array}$ & $\begin{array}{c}33 \\
(13.3)\end{array}$ & $\begin{array}{c}49 \\
(19.8)\end{array}$ & $\begin{array}{c}148 \\
(59.7)\end{array}$ & $\begin{array}{c}12 \\
(4.8)\end{array}$ & 3.51 & .872 \\
\hline $\begin{array}{l}\text { 2. Easy to use to communicate } \\
\text { with students. }\end{array}$ & $\begin{array}{c}9 \\
(3.6)\end{array}$ & $\begin{array}{c}59 \\
(23.8)\end{array}$ & $\begin{array}{c}26 \\
(10.5)\end{array}$ & $\begin{array}{c}134 \\
(54.0)\end{array}$ & $\begin{array}{c}20 \\
(8.1)\end{array}$ & 3.39 & 1.048 \\
\hline $\begin{array}{l}\text { 3. Network systems are not } \\
\text { easy to down. }\end{array}$ & $\begin{array}{c}53 \\
(21.4)\end{array}$ & $\begin{array}{c}100 \\
(40.3)\end{array}$ & $\begin{array}{c}39 \\
(15.7)\end{array}$ & $\begin{array}{c}52 \\
(21.0)\end{array}$ & $\begin{array}{c}4 \\
(1.6)\end{array}$ & 2.41 & 1.091 \\
\hline $\begin{array}{l}\text { 4. The system guarantees the } \\
\text { storage of student assignment } \\
\text { information and scores. }\end{array}$ & $\begin{array}{c}14 \\
(5.6)\end{array}$ & $\begin{array}{c}32 \\
(12.9)\end{array}$ & $\begin{array}{c}42 \\
(16.9)\end{array}$ & $\begin{array}{c}150 \\
(60.5)\end{array}$ & $\begin{array}{c}10 \\
(4.0)\end{array}$ & 3.44 & .963 \\
\hline $\begin{array}{l}\text { 5. The system is capable of } \\
\text { storing large amounts of data. }\end{array}$ & $\begin{array}{c}16 \\
(6.5)\end{array}$ & $\begin{array}{c}47 \\
(19.0)\end{array}$ & $\begin{array}{c}75 \\
(30.2)\end{array}$ & $\begin{array}{c}104 \\
(41.9)\end{array}$ & $\begin{array}{c}6 \\
(2.4)\end{array}$ & 3.15 & .972 \\
\hline $\begin{array}{l}\text { 6. Easy to uploading the } \\
\text { materials. }\end{array}$ & $\begin{array}{c}8 \\
(3.2)\end{array}$ & $\begin{array}{c}39 \\
(15.7)\end{array}$ & $\begin{array}{c}28 \\
(11.3)\end{array}$ & $\begin{array}{c}163 \\
(65.7)\end{array}$ & $\begin{array}{c}10 \\
(4.0)\end{array}$ & 3.52 & .918 \\
\hline $\begin{array}{l}\text { 7. Interface is interesting } \\
\text { (color, font, size) }\end{array}$ & $\begin{array}{c}6 \\
(2.4)\end{array}$ & $\begin{array}{c}66 \\
(26.6)\end{array}$ & $\begin{array}{c}26 \\
(10.5)\end{array}$ & $\begin{array}{c}138 \\
(55.6)\end{array}$ & $\begin{array}{c}12 \\
(4.8)\end{array}$ & 3.34 & 1.001 \\
\hline $\begin{array}{l}\text { 8. Access speed rates are } \\
\text { sufficient. }\end{array}$ & $\begin{array}{c}17 \\
(6.9)\end{array}$ & $\begin{array}{c}95 \\
(38.3)\end{array}$ & $\begin{array}{c}28 \\
(11.3)\end{array}$ & $\begin{array}{c}106 \\
(42.7)\end{array}$ & $\begin{array}{c}2 \\
(.8)\end{array}$ & 2.92 & 1.056 \\
\hline $\begin{array}{l}\text { 9. Has the ability to deal with } \\
\text { viruses / hackers. }\end{array}$ & $\begin{array}{c}6 \\
(2.4)\end{array}$ & $\begin{array}{c}16 \\
(6.5)\end{array}$ & $\begin{array}{c}182 \\
(73.4)\end{array}$ & $\begin{array}{c}40 \\
(16.1)\end{array}$ & $\begin{array}{c}4 \\
(1.6)\end{array}$ & 3.08 & .618 \\
\hline $\begin{array}{l}\text { 10. Helps save time on learning } \\
\text { and programming. }\end{array}$ & $\begin{array}{c}4 \\
(1.6)\end{array}$ & $\begin{array}{c}33 \\
(13.3)\end{array}$ & $\begin{array}{c}43 \\
(17.3)\end{array}$ & $\begin{array}{c}156 \\
(62.9)\end{array}$ & $\begin{array}{c}12 \\
(4.8)\end{array}$ & 3.56 & .842 \\
\hline $\begin{array}{l}\text { 11. Help to improve my work } \\
\text { performance. }\end{array}$ & $\begin{array}{c}12 \\
(4.8)\end{array}$ & $\begin{array}{c}67 \\
(27.0)\end{array}$ & $\begin{array}{c}47 \\
(19.0)\end{array}$ & $\begin{array}{c}106 \\
(42.7)\end{array}$ & $\begin{array}{c}16 \\
(6.5)\end{array}$ & 3.19 & 1.057 \\
\hline $\begin{array}{l}\text { 12. It is an effective and } \\
\text { efficient learning and } \\
\text { facilitating tool. }\end{array}$ & $\begin{array}{c}9 \\
(3.6)\end{array}$ & $\begin{array}{c}32 \\
(12.9)\end{array}$ & $\begin{array}{c}33 \\
(13.3)\end{array}$ & $\begin{array}{c}166 \\
(66.9)\end{array}$ & $\begin{array}{c}8 \\
(3.2)\end{array}$ & 3.53 & .890 \\
\hline $\begin{array}{l}\text { 13. Internet-based and easy to } \\
\text { access everywhere. }\end{array}$ & $\begin{array}{c}4 \\
(1.6)\end{array}$ & $\begin{array}{c}26 \\
(10.5)\end{array}$ & $\begin{array}{c}26 \\
(10.5)\end{array}$ & $\begin{array}{c}166 \\
(66.9)\end{array}$ & $\begin{array}{c}26 \\
(10.5)\end{array}$ & 3.74 & .843 \\
\hline $\begin{array}{l}\text { 14. To improve my learning } \\
\text { and facilitation. }\end{array}$ & $\begin{array}{c}2 \\
(.8)\end{array}$ & $\begin{array}{c}35 \\
(14.1)\end{array}$ & $\begin{array}{c}26 \\
(10.5)\end{array}$ & $\begin{array}{c}173 \\
(69.8)\end{array}$ & $\begin{array}{c}12 \\
(4.8)\end{array}$ & 3.64 & .813 \\
\hline
\end{tabular}

Total of mean

3.32

.620

Notes: $\mathrm{SD}=$ Strongly Disagree, $\mathrm{NA}=$ Not Agree, $\mathrm{NS}=$ Not Sure, $\mathrm{A}=$ Agree, $\mathrm{SA}=$ Strongly Agree

Table 4. Attitudes toward the Use of MYGURU

\begin{tabular}{lcccccccc}
\hline \multicolumn{1}{c}{$\begin{array}{l}\text { No. Items } \\
\text { MYGURU }\end{array}$} & \multicolumn{9}{c}{ Frequency of Responses (\%) } & \multirow{2}{*}{ Mean } & $\begin{array}{r}\text { Standard } \\
\text { Deviation }\end{array}$ \\
\cline { 2 - 7 } & SD & NA & NS & A & SA & & 1.051 \\
\hline $\begin{array}{l}\text { 1. It can be used by anyone } \\
\text { without the need for }\end{array}$ & 10 & 60 & 41 & 117 & 20 & 3.31 & 1.125 \\
expertise in computer skills. & & $(24.2)$ & $(16.5)$ & $(47.2)$ & $(8.1)$ & & \\
$\begin{array}{l}\text { 2, Using it is the same as } \\
\text { reading using a backboard. }\end{array}$ & 33 & 89 & 40 & 79 & 7 & 2.75 & 1.125 \\
\hline & $(13.3)$ & $(35.9)$ & $(16.1)$ & $(31.9)$ & $(2.8)$ & & \\
\hline
\end{tabular}

Notes: $S D=$ Strongly Disagree, NA=Not Agree, $N S=$ Not Sure, A=Agree, SA=Strongly Agree 
The study found that 169 respondents had a negative attitude towards the used of learning management system. The remaining 97 people have positive attitudes. Table 5 shows the frequency, percentage and distribution of learning management system attitude scores on MYGURU.

The results of the Spearman's correlation test showed that there was a significant positive and moderate relationship between perceived usefulness and lecturers' attitude, $r s=.485(p<$ $.05)$. Therefore, the $H 1$ hypothesis is accepted as the positive perception (PU) positively associated with (A) lecturers' attitudes toward the used of learning management system.

\section{Discussion}

The impression of usability on MYGURU is at a moderate level. Findings in line with Sakarji et al., (2019); Islam (2015) state that e-learning is positive which helps in efficient information retrieval. Accessibility gives MYGURU a high positive response from lecturers. This finding was supported by Fauzi \& Azlyzae (2019); Taat \& Francis (2020) state that the ability to use wireless to help access or learning is carried out regardless of location is one of the positive advantages of an application. The mean score for the lecturer's attitude is moderate to positive. This finding is in line with Cakir \& Solak (2015); Fathema, Shannon, \& Ross (2015) who found that participants' perceived value of e-learning was positive. In addition, the attitude of lecturers through the use of MYGURU in UPSI was mostly negative. This finding is contrary to Seyal \& Rahman (2015); Hussein (2017) states that consumer attitudes towards the use of e-learning systems are positive.

Based on the Spearman's correlation between the perceived usefulness and lecturers' attitude shows significant positive and moderate relationship towards the used of learning management system. This finding is supported by
Salloum et al. (2019); Sakarji et al. (2019) stated that the perceived usefulness of the lecturer has a positive relationship in influencing the attitude toward developing my intention. Useful and easy-to-use perceptions are not a major factor in the formation of attitudes and in influencing intentions towards implementing e-learning systems (Hussein, 2017). However, different situations are shown when the notion of ease of use is an important construct for the usefulness and attitude of a technology. This is because when technology is difficult to use, no matter how functional it may be, users will not be attracted (Buabeng-Andoh, Yaokumah, \& Tarhini, 2019). In addition, the perception of technology's use affects users' attitudes and intentions to use them. This will determine the actual use of a technology system by an individual (Yoshida, 2016).

The highest score for perceived usefulness of MYGURU is helps save time on learning and programming with mean value score of 3.56. MYGURU is an effective web based learning especially to cater huge number of class students, and all the evidence teaching and learning activities such as lecturer notes, assignment, forum, quiz and video conference is stored in MYGURU as well as for the long learning distance is efficient. E-learning helps manage the time of the instructor in implementing PdPc sessions with wireless usage capabilities regardless of place and time (Stapa, Ibrahim \& Yusoff, 2017; Fauzi \& Azlyzae, 2019; Taat \& Francis, 2020). Thus, MYGURU provide blended learning tools, where not all the time lecturer have to meet the students for 14 weeks per semester. Instead of having lecturer via face to face with students, they can communicate with all the students via MYGURU platform to have lecture online, save the video lecture online, having forum with the students and easy to trace those students who attend the online class via MYGURU. While, the benefits for the university academic management, the MYGURU are able to monitor

Table 5. Frequency, Percentages and Distribution of Learning Management System Attitude Scores on MYGURU

\begin{tabular}{cccll}
\hline Marks & Frequency & Percentages & Attitude & \\
\hline $2-5$ & 62 & 25.0 & Negative & \multirow{2}{*}{$169(68.1 \%)$} \\
6 & 107 & 43.1 & Negative & \\
$7-10$ & 79 & 31.9 & Positive & $97(31.9 \%)$ \\
\hline Total & $\mathbf{2 4 8}$ & $\mathbf{1 0 0 . 0}$ & & \\
\hline
\end{tabular}


the lecturer activities in line with the Industrial Revolution 4.0 for education and accessible for the accreditation process where the MYGURU can retrieve al the evidences of teaching and learning activities. Therefore, the perceived usefulness of MYGURU not only satisfy of saving time on learning and programming for the lecturer but also cater the needs of the student and university academic management.

The second highest mean score is 3.53 for perceived usefulness is an effective and efficient learning and facilitating tool. As the nation is moving towards to Industrial Revolution 4.0 for education, the teaching and learning can reach beyond classroom walls and connect your online class via single-touch on your smart phone or touch screen monitor. Khalil \& Awani (2018) investigated that there are 25 million $(80 \%)$ out of 31 million of Malaysia population active user for internet access and most of the youth today have smart phone. The students found it easy to reach the lecture via MYGURU platform not just during the formal classroom time for teaching and learning but can reach beyond classroom walls with active learning process and social learning. The data indicated the lecturers have good management in facilitating the process of learning and teaching where easy to monitor the assignment submitted by the student. The assignment form can be essay writing, report writing, project, video (can be uploaded via YouTube link), online quiz and online game. On the other hand, the online platform provide paperless environment and lecturer no longer have to spend so much time running copies or shuffling papers around and will have more time to teach and plan their lesson with more sustainable and efficient workflow.

While the perceived usefulness for easy to uploading the materials is the third highest mean score where lecture the do not have any problem to upload the teaching and learning documents and the students able to download the materials that they required. MYGURU can save the previous semester of lecture notes and carry forward for the next semester. The teaching and learning materials can be updated and replace with the latest version the used for the students. E-learning demonstrates positive uses and helps users to access information more efficiently online (Sakarji et al., 2019).

In addition, the mean score for the easy to use to communicate with students under the perceived usefulness is 3.39 where the data presented the moderate level achievement. The lecturer able to instruct the student regarding forum, assignment, project and quiz to ensure the student understanding in line with the learning outcome of the course. In contrast based on Hamzah (2007) findings, the response lecture on using the MYGURU 2 forum mean score is 3.67 where the interaction discussion between lecturer and students achieved high level results as compare to the mean score results of MYGURU in 2020. This is due to the used of mobile instant messaging such as Whatsapp support become popular and widely applied for teaching and learning in higher education, classroom interaction and discussion, administrative support and language learning (So, 2016; Lauricella \& Kay, 2013; Goh, Seet, \& Chen, 2012). Therefore, the communication via forum in MYGURU become less popular where system required to login and setup the topic to discuss but via WhatsApp the used to extend and re-enforce the concepts learnt in the class, and provide a channel for the students to communicate with the instructor beyond the classroom walls. The challenge for the MYGURU is to have better service than WhatsApp or to be part complement in the MYGURU system where the lecture is easy to access and fast to disseminate the information regarding the teaching and learning to the students.

The lowest mean score (2.41) for PU is network systems are not easy to breakdown which fall under moderate level. This shows that the MYGURU is frequently occurred breakdown as the system is setup in 2004 where the management of UPSI required to take further action to overcome this matter to avoid the user of the system become demotivated. The MYGURU is using the center data or their own server and the system already saved a lot data since 2004 and required more data space to cater the user needs which link to education tool teaching and learning. The MYGURU is the process of upgrade the system in order to cater the latest technology in Learning Management System. MYGURU is not just good provide the software but required to have good hardware system especially the network systems and also have good security system to protect all the important data. Thus, the university also already used the feasibility of outsourcing the management 
of application performance from developers to cloud operators where the system is monitorless model to streamline application deployment by delegating performance management (Grohmann, Nicholson, Iglesias, Kounev, \& Lugones, 2019).

On the other hand, the result for attitude towards the use of MYGURU where the mean value is 3.03 with modest level. However, the findings of the study participants' attitude towards the use of e-learning is modest, but may change in a positive manner if the learning management system meets current user needs (Cakir \& Solak, 2015). Lecturers' attitudes toward technology and their impact on their work performance have been helpful in integrating technology that is more relevant to the teaching process (Elkaseh et al., 2015). The negative attitude can be solved, if the learning management system able to cater the hardware of the specification especially the internet and network. Consumer attitudes towards the use of the system remain positive and significant as consumers believe and believe that e-learning is best used for better information (Seyal \& Rahman, 2015; Fathema et al., 2015; Abidin \& Husseini, 2014).

MYGURU enhanced the learning management system that connecting between the lecturer and students as well as help the management to make any decision to improve the learning facilities that enquired by the lecturer where all the documents teaching and learning is recorded and easy to be access via smart phone, notebook and laptop. The communication between the lecturer and students become more effective and enhanced the creativity of the lecturer to approach the student needs.

This study helps the management of UPSI to understand the MYGURU performance and integrate it into the system in line with the current needs of the lecturers especially launching learning and facilitating sessions. This is important because improving the quality of the system can improve the effectiveness of the learning process. In addition, this study helps the lecturer to state the actual performance of the existing MYGURU system for ICT in terms of its usefulness. This directly helps the lecturer use the MYGURU without having difficulty in furthering each and every case of the learning process. This indirect effect will influence the perception and attitude of the lecturer and thus encourage the use ofMYGURU more proactively.
Furthermore, the study of MYGURU can also help students to use the MYGURU smoothly without the difficulty of applying it during the learning and facilitating process especially in obtaining information from lecturers.

\section{CONCLUSION}

The perceived of usefulness to the MYGURU generally plays a very important role in influencing the level of lecturer acceptance. Through feedback from the respondents, it was found that most respondents expressed agreement on the usefulness of the system. However, the level of attitude expressed by the lecturers is modest. Furthermore, the attitude towards the use of MYGURU certainly has a strong influence on the perceived usefulness of the lecturers. This can be seen when there is a positive relationship between the two attitude variables and their perceived usefulness. The successful factor of the used of MYGURU required a good software application that able to manage the administration, documentation, tracking, reporting, and delivery of educational courses and blended learning as well as have a good specification of hardware in term of provide stable data center or cloud system that stores the data in the public cloud which may exposed to security issues. In light of this, it was found that the notion of usefulness is very much related to the formation of the lecturer's attitude which in turn will determine the attitude of the lecturer whether positive or negative to the use of MYGURU.

\section{ACKNOWLEDGEMENT}

The authors are grateful thank to the Universiti Pendidikan Sultan Idris for the funding of this project grant (2019-0241-109-01). This research is a matching grant between Universiti Pendidikan Sultan Idris and Universitas Negeri Yogyakarta.

\section{REFERENCES}

Abidin, J., \& Husseini, M. (2014). Iranian attitudes and test mode preference: Factors contributing to the acceptance of computerized test. Asian Journal of Assessment in Teaching and Learning, 4(2014), 1-18. https://ejournal.upsi.edu. my/index.php/AJATeL/article/view/1952.

Buabeng-Andoh, C., Yaokumah, W., \& Tarhini, 
A. (2019). Investigating students' intentions to use ICT: A comparison of theoretical models. Education and Information Technologies, 24(1), 643660. doi:10.1007/s10639-018-9796-1.

Cakir, R., \& Solak, E. (2015). Attitude of Turkish EFL learners towards e-Learning through TAM model. Procedia-Social and Behavioral Sciences, 176(2015), 596601. doi:10.1016/j.sbspro.2015.01.515.

Chinyamurindi, W., \& Shava, H. (2015). An investigation into e-learning acceptance and gender amongst final year students. South African Journal of Information Management, 17(1), 1-9. doi:10.4102/ sajim.v17i1.635.

Chiu, C. M., \& Wang, E. T. (2008). Understanding Web-based learning continuance intention: The role of subjective task value. Information \& Management, 45(3), 194-201. doi:10.1016/j.im.2008.02.003.

Cidral, W. A., Oliveira, T., Di Felice, M., \& Aparicio, M. (2018). E-learning success determinants: Brazilian empirical study. Computers \& Education, 122(July), 273290.doi:10.1016/j.compedu.2017.12.001.

Creswell, J. W. (2012). Educational research: Planning, conducting and evaluating quantitative and qualitative research (4 ${ }^{\text {th }}$ ed.). Boston, MA: Pearson Education.

Davis, F. D. (1989). Perceived usefulness, perceived ease of use, and user acceptance of information technology. MIS Quarterly, 13(3), 319-340. doi:10.2307/249008.

DeLone, W., \& McLean, E. (2003). The DeLone and McLean model of information systems success: A ten-year update. Journal of management information systems, 19(4), 9-30. doi:10.1080/07421 222.2003.11045748.

Elkaseh, A. M., Wong, K. W., \& Fung, C. C. (2015). The acceptance of e-learning as a tool for teaching and learning in Libyan higher education. International Journal of Information Technology, 3(4), 1-11. http://www.ipasj.org/IIJIT/IIJIT.htm.
Fathema, N., Shannon, D., \& Ross, M. (2015). Expanding the Technology Acceptance Model (TAM) to examine faculty use of learning management systems (MYGURUs) in higher education institutions. Journal of Online Learning \& Teaching, 11(2), 210-232. http://jolt. merlot.org/Vol11no2/Fathema_0615.pdf.

Fauzi, M., Azlyzae, N., \& Kadir, Z. (2019). Hubungan gaya pembelajaran dan pencapaian pelajar-pelajar semester 1 Diploma Teknologi Maklumat (teknologi digital) di politeknik dengan menggunakan aplikasi pspd e-learning bagi kursus PSPD. [The relationship of learning styles and achievement of the $1^{\text {st }}$ semester students of the Information Technology Diploma (digital technology) in polytechnics using the PSPD e-learning application for PSPD courses]. International Conference on Global Education, 1(1), 808-817. http:// fhum.unespadang.ac.id/index.php/ICGE/ article/view/8.

Goh, T. T., Seet, B. C., \& Chen, N. S. (2012). The impact of persuasive SMS on students' self-regulated learning. British Journal of Educational Technology, 43(4), 624-640. doi:10.1111/j.1467-8535.2011.01236.x.

Grohmann J., Nicholson P. K., Iglesias J. O., Kounev S., \& Lugones, D. (2019). Monitorless: Predicting performance degradation in cloud applications with machine learning. Middleware 2019 - Proceedings of the 2019 20th International Middleware Conference, 149-162. doi:10.1145/3361525.3361543.

Hamzah, M. (2007, 2-5 November). Keberkesanan penggunaan perbincangan atas talian dalam Portal My Guru 2 terhadap pembelajaran di UPSI. [Effective use of online discussions in My Guru Portal 2 for learning at UPSI]. Proceedings of the 1st International Malaysian Educational Technology Convention 2007. Kuala Lumpur: META, pp. 242-247.

Hassanzadeh, A., Kanaani, F., \& Elahi, S. 
(2012). A model for measuring e-learning systems success in universities. Expert Systems with Applications, 39(12), 1095910966. doi:10.1016/j.eswa.2012.03.028.

Ho, C. L., \& Dzeng, R. J. (2010). Construction safety training via e-learning: Learning effectiveness and user satisfaction. Computers \& Education, 55(2), 858-867. doi:10.1016/j.compedu.2010.03.017.

Hussein, Z. (2017). Leading to intention: The role of attitude in relation to technology acceptance model in e-learning. Procedia Computer Science, 105(2017), 159-164. doi:10.1016/j.procs.2017.01.196.

Ibrahim, R., Leng, N. S., Yusoff, R. C. M., Samy, G. N., Masrom, S., \& Rizman, Z. I. (2017). E-learning acceptance based on technology acceptance model (TAM). Journal of Fundamental and Applied Sciences, 9(4), 871-889. doi:10.4314/jfas. v9i4s.50.

Islam, N. (2014). Sources of satisfaction and dissatisfactionwithalearning management system in post-adoption stage: A critical incident technique approach. Computers in Human Behavior, 30(2014), 249-261. doi:10.1016/j.chb.2013.09.010.

Khalil, I. H., \& Awani, A. (2018, 30 January). Malaysia negara ke-9 paling aktif media social, ke-5 paling ramai guna e-dagang. [Malaysia is the 9th most active social media country, the 5th most crowded for e-commerce]. Astro Awani News. http://www.astroawani.com/gaya-hidup/ malaysia-negara-ke-9-paling-aktifmedia-sosial-ke-5-paling-ramai-guna-edagang-laporan-166998.

Krejcie, R. V., \& Morgan, D. W. (1970). Determining sample size for research activities. Educational and psychological measurement, 30(3), 607-610. doi: $10.1177 / 001316447003000308$.

Lauricella, S., \& Kay, R. (2013). Exploring the use of text and instant messaging in higher education classrooms. Research in Learning Technology, 21(1), 1-17. doi:10.3402/rlt.v21i0.19061.
Liaw, S. S., \& Huang, H. M. (2011). A study of investigating learner's attitudes toward e-learning. In Proceedings of 5th International Conference on Distance Learning and Education 2. Singapore: IACSIT Press, pp. 28-32.

Lin, S. C., Persada, S. F., \& Nadlifatin, R. (2014). A study of student behavior in accepting the Blackboard Learning System: A Technology Acceptance Model (TAM) approach. In Proceedings of the 2014 IEEE 18th international conference on computer supported cooperative work in design (CSCWD). Hsinchu: IEEE, pp 457-462. doi:10.1109/ CSCWD.2014.6846888.

Razak, R. A. (2017). Strategi pembelajaran aktif secara kolaboratif atas talian dalam analisis novel bahasa melayu. [Active learning strategies in a collaborative online novel analysis of the Malay language]. JuKu: Jurnal Kurikulum \& Pengajaran Asia Pasifik, 1(3), 34-46. https://juku. um.edu.my/article/view/7961.

Richter, J., Hale, A. E., \& Archambault, L. M. (2019). Responsible innovation and education: integrating values and technology in the classroom. Journal of Responsible Innovation, 6(1), 98-103. doi: 10.1080/23299460.2018.1510713.

Rivas, A., Fraile, J. M., Chamoso, P., GonzálezBriones, A., Rodríguez, S., \& Corchado, J. M. (2019). Students performance analysis based on machine learning techniques In: L. Uden, D. Liberona, G. Sanchez, S. Rodríguez-González (Eds). Learning technology for education challenges: Communications in computer and information science, vol 1011. Zamora, Spain: Springer. doi:10.1007/978-3-03020798-4_37.

Sakarji, S. R., Nor, K. B. M., Razali, M. M., Talib, N., Ahmad, N., \& Saferdin, W. A. A. W. M. (2019). Investigating student's acceptance of e-learning using technology acceptance model among diploma in office management and technology students at UITM Melaka. Journal of 
Information, 4(13), 13-26. doi: 10.35631/ JISTM.413002.

Salloum, S. A., Alhamad, A. Q. M., Al-Emran, M., Monem, A. A., \& Shaalan, K. (2019). Exploring students' acceptance of e-learning through the development of a comprehensive technology acceptance model. IEEE Access, XX(2019), 1-9. doi:10.1109/ACCESS.2019.2939467.

Seyal, A. H., \& Rahman, M. N. A. (2015). Understanding learning styles, attitudes and intentions in using e-learning system: Evidence from Brunei. World Journal of Education, 5(3), 61-72. doi:10.5430/wje. v5n3p61.

So, S. (2016). Mobile instant messaging support for teaching and learning in higher education. The Internet and Higher Education, 31(2016), 32-42. doi:10.1016/j.iheduc.2016.06.001.

Stapa, M. A., Ibrahim, M., \& Yusoff, A. (2017). Kolaborasi dalam pendidikan vokasional: Mewujudkan pembelajaran teradun melalui teknologi web 2.0. Collaboration in vocational education: Realizing integrated learning through web 2.0 technology]. Journal of ICT in Education, 4, 35-51. https://ejournal.upsi.edu.my/ index.php/JICTIE/article/view/2616.

Taat, M. S., \& Francis, A. (2020). Factors influencing the students' acceptance of e learning at teacher education institute: An exploratory study in Malaysia. International Journal of Higher Education, 9(1), 133-141. doi:10.5430/ ijhe.v9n1p133.

Yeop, M. A. (2016). Pembelajaran teradun: Satu tinjauan literatur terhadap faktorfaktor penerimaan guru melalui modelmodel penerimaan. [Intergrated learning: A literature review of the factors of teacher acceptance through models of acceptance]. Journal of Research, Policy \& Practice of Teachers \& Teacher Education (JRPPTTE), 6(1), 67-85.

Yoshida, H. (2016). Perceived usefulness of" flipped learning" on instructional design for elementary and secondary education: With focus on pre-service teacher education. International Journal of Information and Education Technology, 6(6), 430-434. doi:10.7763/IJIET.2016. V6.727.

Zemudin, N. A. M., \& Salleh, M. A. M. (2017). Mudah guna dan kebergunaan laman web universiti dalam kalangan pelajar antarabangsa. [Ease of use and usefulness of university web site among international students]. e-Bangi, 14(1), 1-12. http://ejournal.ukm.my/ebangi/ article/view/18292. 